\title{
Bioclimatic distribution and prevalence maps for Fasciola hepatica in Espírito Santo State, Brazil
}

\author{
Deivid França Freitas ${ }^{1}$, Isabella VF Martins ${ }^{1,5^{*}}$, Gleissy MADA dos Santos ${ }^{2}$, Alexandre R dos Santos ${ }^{3}$ \\ and Daniel da Silva Gomes ${ }^{4}$
}

\begin{abstract}
Background: Fasciolosis affects different ruminant species and leads to great economic losses for cattle farmers worldwide. Thus, the current study aimed to evaluate bovine fasciolosis prevalence in the state of Espírito Santo, Brazil, using slaughter maps provided by slaughterhouses and verifying the origin of cattle.

Methods: A map was created based on analysis of epidemiological data. The ArcGIS/ArcINFO 10.1 software was employed in order to elaborate updated bioclimatic maps that displayed the fasciolosis prevalence within the state per city- between 2009 and 2011.

Results: According to the bioclimatic map it was clear that $52.24 \%$ of the state's total area comprise regions considered favorable for the development and survival of Fasciola hepatica. According to the data provided by slaughterhouses, the parasite was more frequent in the cities of Atílio Vivácqua, Itapemirim and Anchieta with respective prevalence of $28.41,25.50$ and $24.95 \%$. Although the northern portion of the state is also favorable for the disease maintenance (reaching rates above 90\%), several cities presented prevalence of only 0.99 and $1.94 \%$ respectively. These findings indicate that climatic and environmental factors only cannot be considered preponderant to fasciolosis occurrence. Regarding the slaughterhouse located in Anchieta city, the higher prevalence was registered in the cities of Jerônimo Monteiro, Alegre and Cachoeiro de Itapemirim, with mean prevalence of $1.21,1.07$ and $2.09 \%$ respectively.
\end{abstract}

Conclusion: Although the present findings suggest a pattern for the prevalence of fasciolosis, records of the cities for the occurrence of the disease usually do not reflect the true origin of animals.

Keywords: Maps, Geographic information system (GIS), Prevalence, Fasciola hepatica

\section{Background}

Fasciolosis is a parasitosis that affects cows, buffalos, donkeys, sheep and occasionally human beings [1]. Originally from Europe, the trematoda Fasciola hepatica successfully increased its geographic boundaries and nowadays can be found in all the continents. Besides restrictions imposed by its biology and ecology, the parasite holds a cosmopolitan distribution that ranges from temperate regions up to the tropics [2].

In following up the impact of fasciolosis in cattle farming around the world, it is noticeable that economic losses

\footnotetext{
* Correspondence: isabella@cca.ufes.br

'Graduate Program in Veterinary Sciences, School of Veterinary Sciences,

Federal University of Espírito Santo, Alegre, Espírito Santo State, Brazil

${ }^{5}$ Centro de Ciências Agrárias, Universidade Federal do Espírito Santo, Alegre,

Espírito Santo, Brasil

Full list of author information is available at the end of the article
}

are considerable once they can overpass US $\$ 2$ billion a year. Such losses comprise decrease in dairy production, reduction in animal weight, slow development and fertility impairment, besides the discard of a large number of infected livers found in slaughterhouses [3].

Due to its strong dependence on weather and environment, it is observed that the distribution and prevalence of the disease is higher in places where mean temperatures vary from $10^{\circ} \mathrm{C}$ to a little more than $25^{\circ} \mathrm{C}$ [4].

Factors such as rainfall, air relative humidity, soil conditions and flooded areas are important for the development and survival of the parasite $F$. hepatica. It is also known that flooded lands are necessary to the occurrence of aquatic mollusks from the genus Lymnaea - intermediate hosts of the larval stages of trematoda [5]. 
The first reports, in Brazil, about the disease came from the state of Rio de Janeiro around 1920 [6]. Since then, cases of fasciolosis have often been recorded throughout the country. The disease have been registered mainly in the South and Southeast, due to high infection indexes observed in these areas $[7,8]$.

Based on these records, the existence of possible risk areas for fasciolosis in the South of the state of Espírito Santo was hypothesized [9]. Martins et al. [10] found eggs of the parasite in feces of animals slaughtered in this region when they were evaluating the efficiency of a sedimentation technique.

As new technologies arose, the use of geographic information systems (GIS) became mandatory because of their contributions to cartographic data, particularly in spatial and temporal epidemiological models used to categorize transmission risks of certain diseases [11].

Bioclimatic risk is highlighted among the mechanisms developed by GIS. It aims to quantify risks according to the background of adverse events based on epidemiology and local climate. It is known that distribution is a broadly applied technique to identify regions most favorable to the development of many cultures [12]. Therefore, it is worth using such technique as a veterinarian epidemiology tool, once the dispersion and establishment of many parasitic diseases are deeply linked to environmental and climatic factors.

Thus, the present study aimed to elaborate a bioclimatic distribution for F. hepatica in the state of Espírito Santo using GIS and data about the prevalence of bovine fasciolosis provided by slaughterhouses registered at the federal and state inspection systems (SIF and SIE) of the Brazilian Ministry of Agriculture, Livestock and Supply (MAPA).

\section{Methods}

\section{Studied location}

The state of Espírito Santo holds a $46.184,1 \mathrm{~km}^{2}$ area divided into 78 cities and it is geographically located between meridians $39^{\circ} 38^{\prime}$ and $41^{\circ} 50^{\prime}$ west longitude and between parallels $17^{\circ} 52^{\prime}$ and $21^{\circ} 19^{\prime}$ south latitude.

Mean altitude is $600-700 \mathrm{~m}$ and presents quite rough topography, archeozoic lands with isolated peaks about $2.890 \mathrm{~m}$ high. The edge of the highlands presents itself as a mountain zone and it is crossed by rivers that open deep valleys, which creates flooding zones during rainfall periods [13].

It is known that Espírito Santo holds two main climatic types: tropical rainy and humid mesothermal. The first one dominates the lowlands and is characterized by high temperatures throughout the year and average temperature above $22^{\circ} \mathrm{C}$. The humid mesothermal climate - which has no dry season - is found in mountain areas in the south of the state. It is characterized by low temperatures in the winter and medium in the colder months (bellow $18^{\circ} \mathrm{C}$ ). According to Köppens' classification, the climate is $A w$-warm and humid (tropical rainy), presenting rain in summer and drought in winter (sub-drought in August) [14].

\section{Bioclimatic research for the occurrence of fasciolosis}

Data recorded during 30 years were used to elaborate distribution maps for fasciolosis in the state of Espírito Santo. The information was dereived from 109 weather stations located in the state and bordering areas, which favored data interpolations and the application of the hydric balance according to Thornthwaite and Matter [15].

\section{Statistical analysis and cartographic data generation}

After data analysis using the ArcGIS/ArcINFO 10.1 software, charts of hydric balance were imported to generate punctual spatial vectors from meteorological stations and their respective attribute tables. Afterwards, the multiple linear regression was applied. It utilized altitude and geographic coordinates - longitude $(\mathrm{X})$ and latitude $(\mathrm{Y})$ - as independent variables of Mercator Transverse Universal System (UTM). Temperature was the dependent variable. Data were made available in attribute tables of hydric balance, as described below, by the multiple regression equation:

$$
T=\beta_{0}+\beta_{1} A L T+\beta_{2} X+\beta_{3} Y
$$

In which:

T: temperature $\left({ }^{\circ} \mathrm{C}\right)$;

ALT: altitude (m);

$\mathrm{X}$ : coordinates UTM X (m);

Y: coordinates UTM Y $(\mathrm{m})$;

$\beta_{0}$ : constant of regression;

$\beta_{1}, \beta_{2}$ and $\beta_{3}$ : coefficient of regression for the variables ALT, $X$ and $Y$.

Thus, matrix images of longitude $(\mathrm{X})$ and latitude were generated by means of a spatial interpolation using the Spherical Kriging Method and imported into the application ArcGIS/ArcINFO 10.1. The Elevation Digital Model (EDM) from the Shuttle Radar Topography Mission (SRTM) project was also generated and made available by the Brazilian Enterprise for Agricultural Research (EMBRAPA) following the scale 1:250.000 in the cartographic projection WGS84.

Four variables featuring the distribution of fasciolosis were developed by means of a mathematical model combined with GIS. They were inserted in a database according to their relevance to the disease. Therefore, weights varying from 1 to 3 , were adopted and divided into areas that presented high, intermediate and low favorability for fasciolosis in Espírito Santo. 
The spatial reclassification was applied to matrix images of altitude, temperature and rainfall in order to highlight regions of capability, restrictiveness and infeasibility, as shown in Table 1.

Such values were based on studies that have assumed infeasible temperatures: below $10^{\circ} \mathrm{C}$, restricted to $10-15^{\circ} \mathrm{C}$ and higher than $25^{\circ} \mathrm{C}$. They also considered optimum temperatures - from $10^{\circ} \mathrm{C}$ up to $26^{\circ} \mathrm{C}$, besides favorable altitudes, those set between 0 and $500 \mathrm{~m}$ above sea level, as well as steepness values up to $10 \%[16,17]$. It is known that favorable altitudes might be higher than $1000 \mathrm{~m}$, as in cases of fasciolosis reported in the Andes [18]. The current study made an option for rates that better represent local conditions.

The "cross tabulating" function was applied in order to develop a bioclimatic distribution able to meet the occurrence of fasciolosis. Thus, matrix images representing the bioclimatic division were converted into a polygonal vector format. The "polygonal dissolution" function was applied in order to obtain the vector image, due to the large numbers of polygons.

The "geometric calculation" function was applied to calculate the respective areas $\left(\mathrm{km}^{2}\right)$ and perimeters $\left(\mathrm{km}^{2}\right)$ of the mentioned aptitude classes. It was done by using attributes resulting from polygonal vector images found in the GIS environ.

\section{Bioclimatic distribution for the $\mathbf{7 8}$ cities}

In order to develop an individual bioclimatic map for each one of the 78 counties in the state, the "intersection" function was applied to polygonal vector images from the cities and to distribution that totalized two new polygonal vector images representing the bioclimatic zone in each city.

\section{Collecting data from Fasciola hepatica infection}

Data about discarded bovine livers from animals slaughtered throughout the state of Espírito Santo were made available by means of slaughter maps showing infection rates of $F$. hepatica in 11 slaughterhouses registered at the federal and state inspection systems (SIF and SIE) of the Brazilian Ministry of Agriculture, Livestock and Supply between 2009 and 2011. The aforementioned scenario took the location of slaughterhouses into acccount. At the same time, only a slaughterhouse in Anchieta city - south of Espírito Santo - provided data about the origin of animals. The existing correlation found between aptitude areas and the respective mean fasciolosis prevalence in Espírito Santo was calculated by means of the Pearson correlation coefficient with significance level of $95 \%$.

\section{Developing the final prevalence maps}

Data provided by slaughterhouses (SIF and SIE) as well as information about the origin of animals from the slaughterhouse in Anchieta city were used in order to develop bovine fasciolosis prevalence maps in the state of Espírito Santo. The ordinary spherical Kriging technique was used to generate cartographic maps. According to Landim [19], the method tries to minimize estimated variances based on preview regression models. He took into account the stochastic dependency among data geospatially distributed.

All the procedures required by the methodology are represented in Figure 1.

\section{Results}

\section{Prevalence of fasciolosis}

The bioclimatic map for the state of Espítito Santo which was based on temperature, rainfall, altitude and steepness variables (Figure 2) - had shown that 52.25\% of areas within the state are located in regions that favor the development of Fasciola hepatica and its intermediate hosts whereas $47.75 \%$ of the areas are not suitable for them.

Therefore, maps generated by distribution, based on rates of prevalence from 11 slaughterhouses distributed throughout the state and monitored by SIF and SIE were combined. Results indicated that slaughterhouses in Atílio Vivácqua, Cachoeiro de Itapemirim and Anchieta presented higher rates of discarded livers, with mean prevalence of 28.41, 25.50 and 24.95\% respectively (Table 2).

Regarding data presented in Figure 3, it was observed that maps generated by distribution showed areas with higher significance for the occurrence of the disease in the south of the state. They presented average rates that varied from 1.21 to $28.41 \%$.

In the extreme North of the state, Montanha showed $0.99 \%$ of prevalence. Although this city is within the

Table 1 Attributes and their relative weights according to the potential risk of fasciolosis in Espírito Santo state, Brazil

\begin{tabular}{lccc}
\hline Variable & \multicolumn{1}{c}{ Relative weight } & 2 - Restrictive $^{\mathbf{1}}$ & $\mathbf{3 ~ - ~ I m p r a c t i c a b l e ~}^{\mathbf{1}}$ \\
\cline { 2 - 4 } & $\mathbf{1}$ - Suitable & & $>1000 \mathrm{~m}$ \\
\hline Altitude & $0-500 \mathrm{~m}$ & $500-1000$ & $<10^{\circ} \mathrm{C}$ \\
\hline Temperature & $15-25^{\circ} \mathrm{C}$ & $10-15^{\circ} \mathrm{C}$ and $>25^{\circ} \mathrm{C}$ & Above $15 \%$ \\
\hline Slope & Until $10 \%$ & 10 to $15 \%$ & $>2500 \mathrm{~mm} /$ year \\
\hline Rainfall & $1000-2500 \mathrm{~mm} /$ year & $>1000 \mathrm{~mm} /$ year &
\end{tabular}

${ }^{1}$ (1) Suitable region, (2) restrictive region and (3) impracticable region for the occurrence of fasciolosis. 


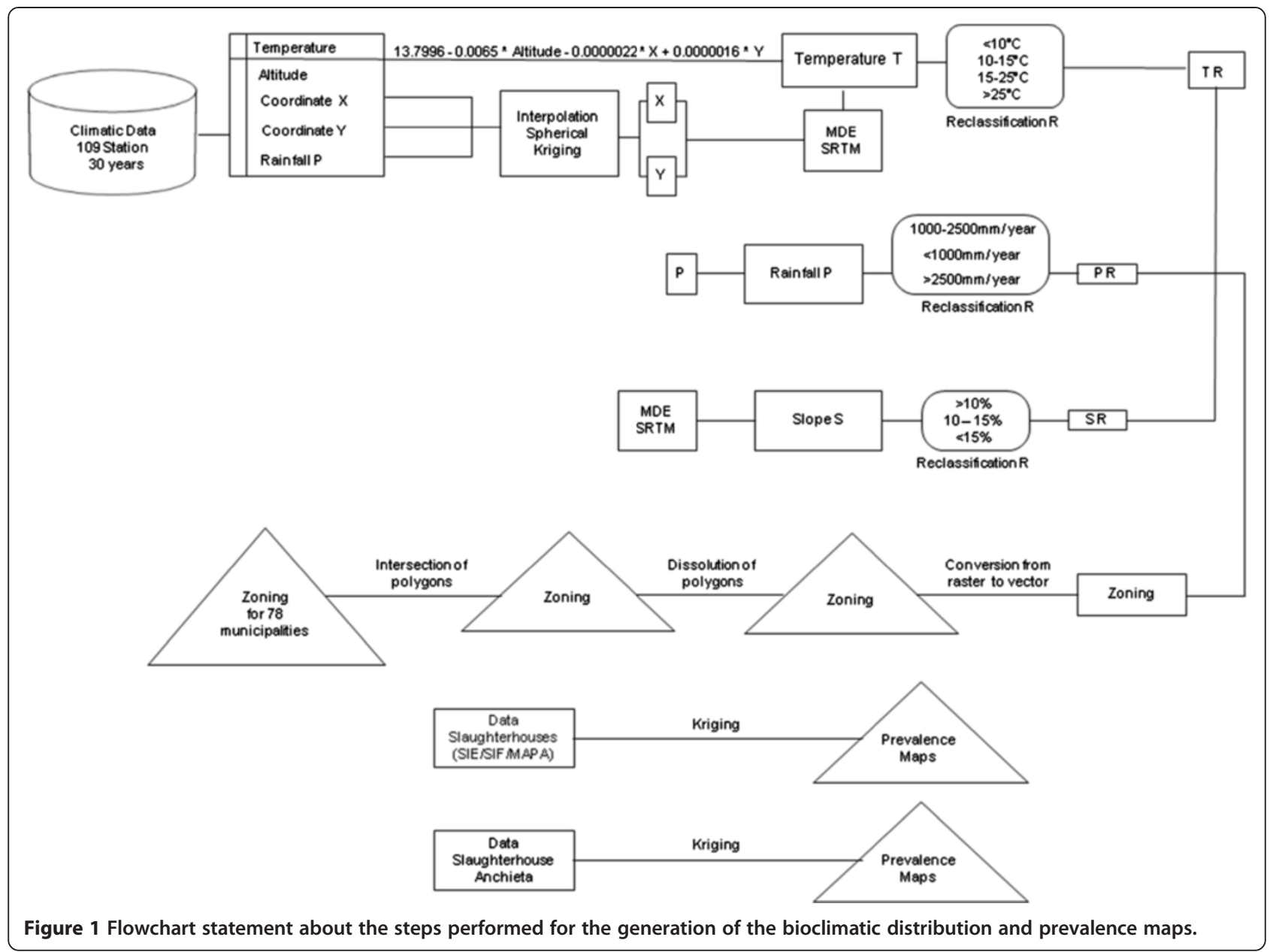

range aptitude for the disease, that is $94.81 \%$, it did not register any higher prevalence than the average found during the three years of the study (Table 2).

\section{Prevalence of fasciolosis in a slaughterhouse in Anchieta city, southern Espírito Santo}

The geospatial distribution of mean prevalence rates recorded in the slaughterhouse of Anchieta, as aforementioned, indicated high prevalence for fasciolosis in municipalities situated in the southern region of the state, with values ranging from 0.01 to $2.09 \%$ (Figure 4). The cities that stood out were Jerônimo Monteiro, Alegre and Cachoeiro de Itapemirim, with averages of 1.21, 1.07 and $2.09 \%$ respectively (Table 3 ).

Regarding the distribution of cities based on the origin of positive animals, the correlation between capable areas and prevalence rates was 0.09 . It was considered a weak correlation.

\section{Discussion}

For the elaboration of a plan of effective control against fasciolosis it is necessary an epidemiological approach that takes into account local and regional issues, in order to reduce the use of anthelmintics, and that corroborates the idea of an integrated management control based on the rational use of products available in the market, which also monitors the emergence of resistance. Thus, the use of geographic information systems agrees with the current needs of the biotech market and veterinary medicine, since it is seen as a preventive tool that helps the producer to make decisions aiming for reduction of losses.

It is noticed the existence of a pattern in prevalence data from slaughterhouses. The origin of animals is not always taken into account and is limited to the reports of slaughterhouses. The present work aimed to demonstrate data on the prevalence of fasciolosis - provided by slaughterhouses registered at federal and state inspection systems and by a slaughterhouse in the southern region of the state - in order to offer a better understanding on the source of the infected animals.

The maps displayed in the present study were generated based on bioclimatic distribution, in which suitable areas are located in zones considered favorable to the 


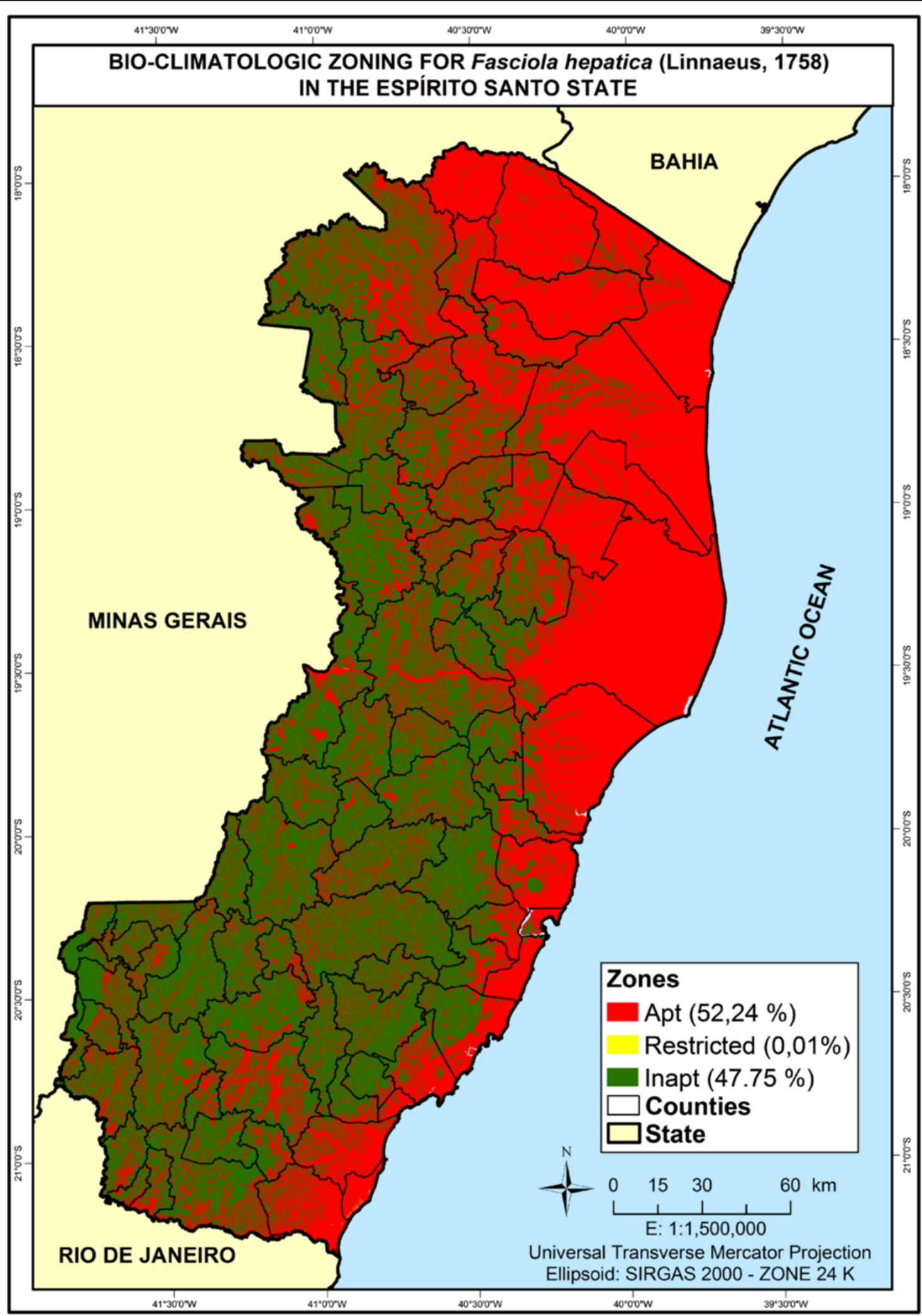

Figure 2 Bioclimatic distribution of $F$. hepatica in Espírito Santo and suitability for its development in the state. 
Table 2 Environmental suitability for bovine fasciolosis and its mean prevalence from 2009 to 2011 regarding distribution by counties in Espírito Santo state according to slaughter maps provided by the Institute of Agricultural and Forestry Defense of Espírito Santo State (IDAF)

\begin{tabular}{|c|c|c|c|c|c|c|c|}
\hline \multirow[t]{2}{*}{ Cities } & \multirow[t]{2}{*}{ Area $\left(\mathrm{km}^{2}\right)$} & \multicolumn{2}{|c|}{ Suitability (\%) } & \multicolumn{4}{|c|}{ Mean prevalence (\%) } \\
\hline & & Suitable & Unsuitable & 2009 & 2010 & 2011 & 3 years \\
\hline Anchieta & 405.32 & 65.06 & 34.94 & 27.64 & 25.94 & 21.27 & 24.95 \\
\hline Aracruz & 1435.81 & 89.07 & 10.93 & 0.04 & 0.00 & 0.00 & 0.01 \\
\hline Atílio Vivácqua & 226.86 & 33.42 & 66.58 & 28.25 & 28.04 & 28.93 & 28.41 \\
\hline Cachoeiro de Itapemirim & 877.31 & 39.56 & 60.44 & - & - & $25.50^{*}$ & 25.50 \\
\hline Cariacica & 275.74 & 52.55 & 47.45 & 0.68 & 0.00 & 0.00 & 0.23 \\
\hline Colatina & 1426.02 & 33.98 & 66.02 & 0.03 & 0.02 & 0.04 & 0.03 \\
\hline Linhares & 3500.19 & 90.71 & 9.29 & 0.00 & 0.00 & 5.83 & 1.94 \\
\hline Montanha & 1096.65 & 94.81 & 5.19 & 1.80 & 0.89 & 0.30 & 0.99 \\
\hline Muniz Freire & 679.78 & 16.41 & 83.59 & 4.63 & 7.07 & 10.55 & 7.42 \\
\hline São Domingos do Norte & 299.80 & 45.27 & 54.73 & 0.04 & 0.00 & 0.05 & 0.03 \\
\hline São Gabriel da Palha & 434.83 & 47.23 & 52.77 & 0.26 & 0.42 & 0.17 & 0.28 \\
\hline
\end{tabular}

*The slaughterhouse in Cachoeiro de Itapemirim city only began operations in 2011.

development of Fasciola hepatica and its intermediate hosts, given that mean temperature and annual rainfall in such places meet limits and are considered positive for the parasite survival and maintenance. They present temperature variations around $25^{\circ} \mathrm{C}$ or more and rainfall averages between 1000 and $2500 \mathrm{~mm} /$ year [20].

It is worth highlighting - based on information from maps generated by distribution and mean prevalence rates from slaughterhouses located in Atílio Vivácqua, Cachoeiro de Itapemirim and Anchieta - that despite the fact that Cachoeiro de Itapemirim city presented elevated percentages (Table 2), the local slaughterhouse initiated its activities in 2011. Such findings corroborate studies performed by Bernardo et al. [21]. They reported $24.89 \%$ prevalence of fasciolosis in a slaughterhouse in the south of Espírito Santo. Martins et al. [10], who tested the sensitivity of a previously reported technique in Atílio Vivácqua, found that $14.14 \%$ of the studied animals were parasitized by $F$. hepatica. Corroborating these results, Alves et al. [22] found the presence of F. hepatica in several rural properties located in the south of Espírito Santo state.

Similar results were also found by Dutra et al. [23] in the south of Brazil. They mentioned 29.51\% of discarded livers in the following states: Santa Catarina, Paraná and Rio Grande do Sul. Other studies had already reported the presence of mollusks of the genus Lymnaea in considerably less extensive areas, but with higher prevalence rates. This species of mollusk is considered an important factor to the occurrence of the disease [9]. Bernard et al. [21] found high prevalence of fasciolosis in cities also situated in less suitable regions, which proves that even in these areas the biological factor, i. e. the presence of mollusks, may be fundamental for the occurrence of the disease.
After analyzing the north region of Espírito Santo, an information gap was observed regarding data collection procedures adopted by the Laboratory of Malacology of the Federal University of Espírito Santo for mollusks of the genus Lymnaea. Somehow, it indicates that such snails - intermediate hosts of F. hepatica - did not colonize or establish successful colonies in the region. Thus, the existence of positive cases of F. hepatica infection can be related to the transportation of animals to other cities and neighbor states such as Minas Gerais and Bahia [24].

The correlation between suitable areas in the state of Espírito Santo and fasciolosis prevalence was 0.31. Such result reinforces the hypothesis related to the transportation of animals from one region to another, trade among farmers and absence of intermediate hosts in more suitable places, keeping the prevalence low.

It is known that factors that influence the occurrence of fasciolosis in a certain region are connected to the availability of adequate biotopes to the development of snails. Therefore, the proportion of recorded infections in Montanha could be connected to the circulation of animals coming from other regions. Such regions usually present positive cases of the disease, even when there is no record of intermediate hosts in them [25,26].

The analysis of the central, northeast and northwest regions of the state showed that Linhares had an infection rate of $1.94 \%$. It strongly influenced the distribution limits, once interpolation can lead to a tendency of growth in susceptible areas towards west. Prevalence rates from slaughterhouses in neighbor counties were considerably lower and had values varying from 0.01 up to $0.28 \%$.

Such result is supported by Namikawa [27] who stated that local interpolator sites used for preparation of GIS maps lead to complete changes within local values, once 


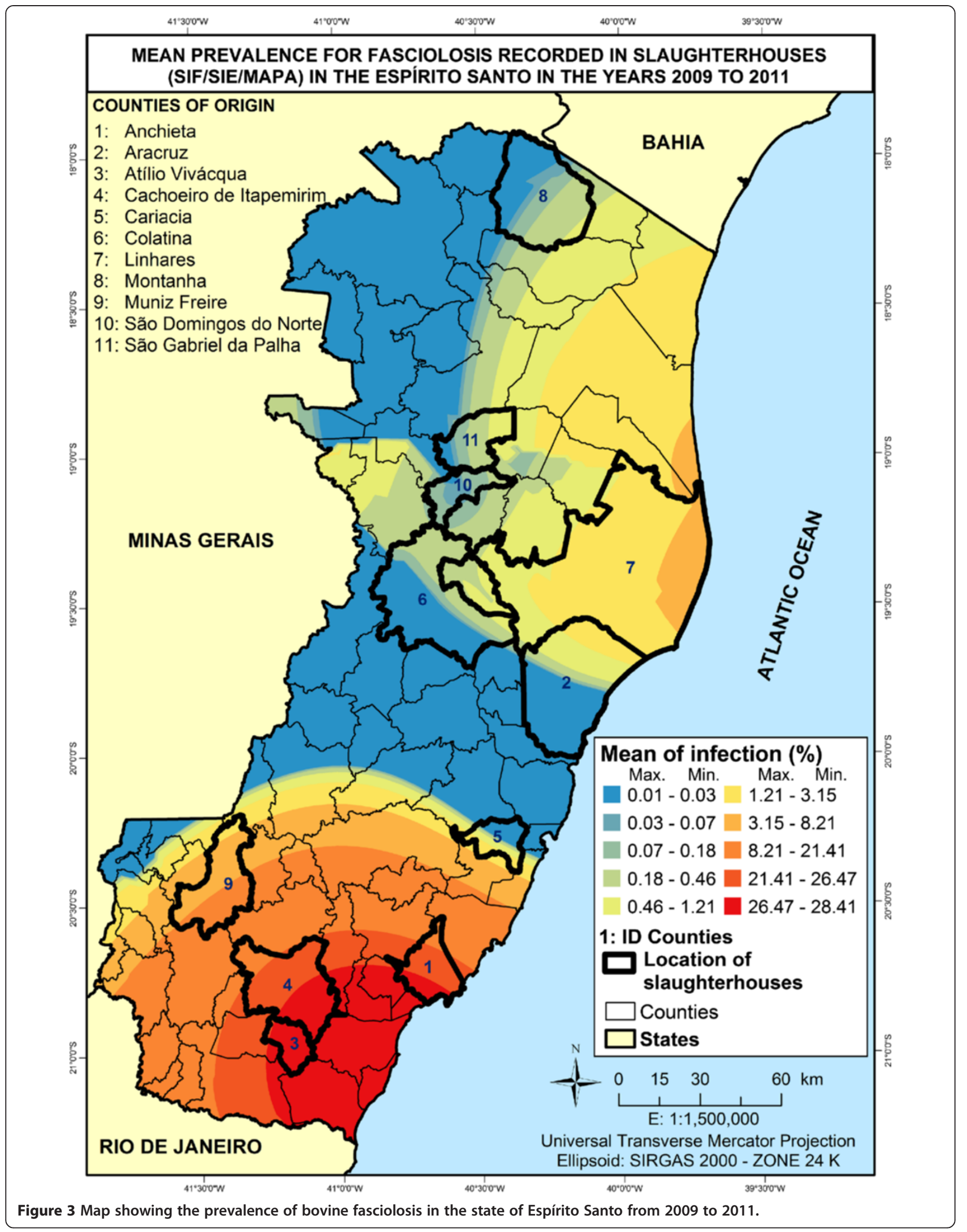




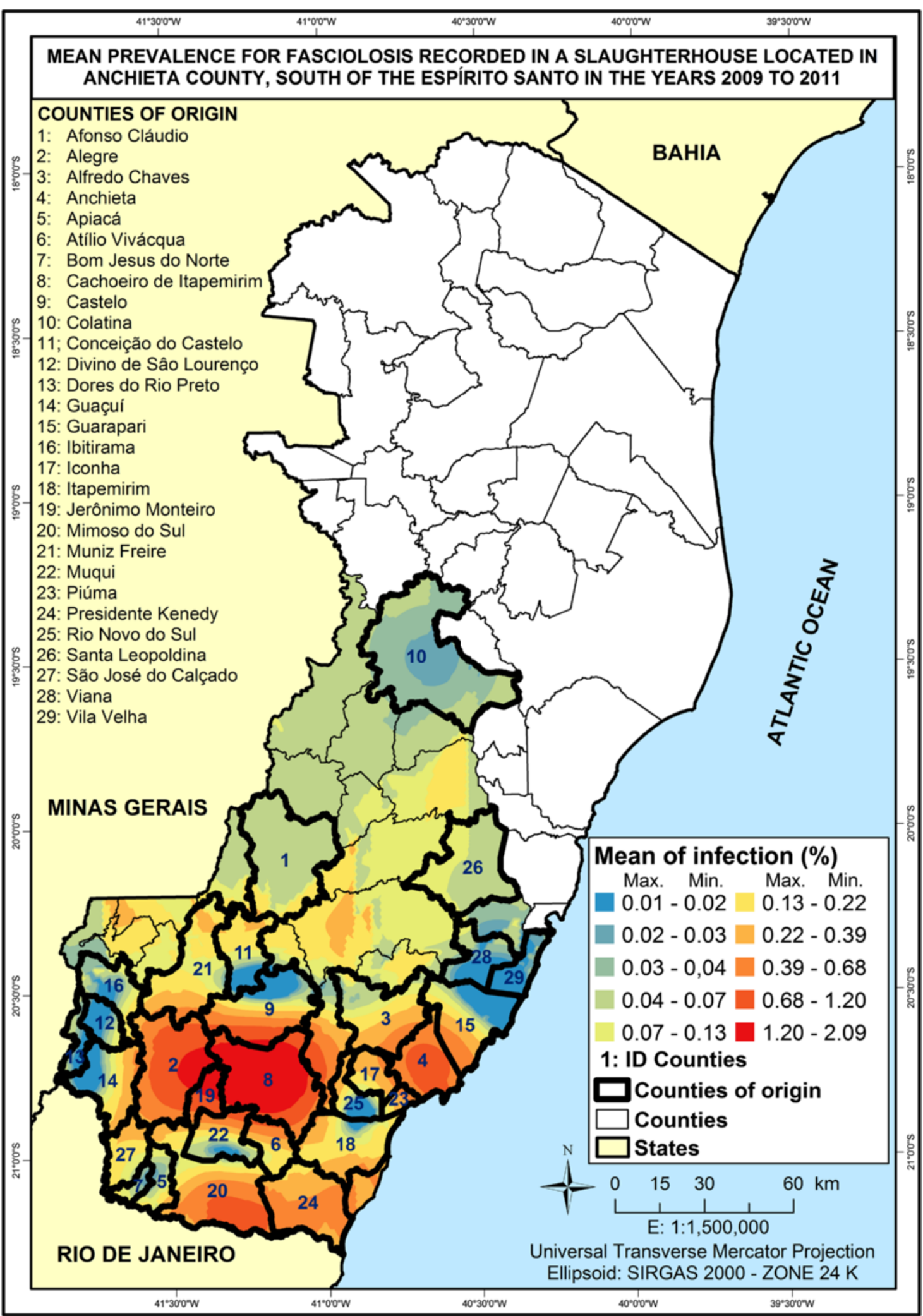

Figure 4 Map showing the prevalence of bovine fasciolosis and its origins in Espírito Santo from 2009 to 2011 according to data provided by a slaughterhouse located in Anchieta. 
Table 3 Suitability for bovine fasciolosis and mean prevalence between 2009 and 2011 according to its origin by cities in the Espírito Santo state

\begin{tabular}{|c|c|c|c|c|c|c|c|c|}
\hline \multirow[t]{2}{*}{ Counties } & \multirow{2}{*}{$\begin{array}{c}\text { Area }\left(\mathrm{km}^{2}\right) \\
\text { Area }\end{array}$} & \multirow{2}{*}{$\begin{array}{c}\text { Suitability (\%) } \\
\text { Suitable }\end{array}$} & \multicolumn{6}{|c|}{ Mean prevalence (\%) } \\
\hline & & & Unsuitable & Restrict & 2009 & 2010 & 2011 & 3 years \\
\hline Afonso Cláudio & 955.26 & 19.24 & 80.76 & 0.00 & 0.14 & 0.00 & 0.01 & 0.05 \\
\hline Alegre & 773.40 & 23.71 & 76.29 & 0.00 & 1.06 & 1.47 & 0.68 & 1.07 \\
\hline Alfredo Chaves & 616.57 & 17.99 & 82.01 & 0.00 & 0.00 & 0.32 & 0.12 & 0.15 \\
\hline Anchieta & 405.32 & 65.06 & 34.94 & 0.00 & 0.29 & 1.35 & 0.74 & 0.79 \\
\hline$\overline{\text { Apiacá }}$ & 193.67 & 37.39 & 62.61 & 0.00 & 0.03 & 0.09 & 0.00 & 0.04 \\
\hline Atílio Vivácqua & 226.86 & 33.42 & 66.58 & 0.00 & 0.03 & 0.49 & 0.16 & 0.23 \\
\hline Bom Jesus do Norte & 89.67 & 33.10 & 66.90 & 0.00 & 0.14 & 0.00 & 0.00 & 0.05 \\
\hline Cachoeiro de Itapemirim & 877.31 & 39.56 & 60.44 & 0.00 & 2.34 & 1.44 & 2.50 & 2.09 \\
\hline Castelo & 668.98 & 21.63 & 78.37 & 0.00 & 0.00 & 0.03 & 0.49 & 0.17 \\
\hline Colatina & 1426.02 & 33.98 & 66.02 & 0.00 & 0.00 & 0.00 & 0.05 & 0.02 \\
\hline Conceição do Castelo & 364.82 & 20.82 & 79.18 & 0.00 & 0.19 & 0.12 & 0.08 & 0.13 \\
\hline Divino de São Lourenço & 175.81 & 26.92 & 73.08 & 0.00 & 0.00 & 0.04 & 0.00 & 0.01 \\
\hline Dores do Rio Preto & 152.78 & 21.03 & 78.97 & 0.00 & 0.09 & 0.01 & 0.00 & 0.03 \\
\hline Guaçuí & 468.88 & 31.72 & 68.28 & 0.00 & 0.03 & 0.22 & 0.00 & 0.08 \\
\hline Guarapari & 595.07 & 50.00 & 50.00 & 0.00 & 0.03 & 0.20 & 0.12 & 0.11 \\
\hline Ibitirama & 330.00 & 21.42 & 78.58 & 0.00 & 0.00 & 0.03 & 0.00 & 0.01 \\
\hline Iconha & 202.61 & 19.11 & 80.89 & 0.00 & 0.06 & 0.51 & 0.20 & 0.26 \\
\hline Itapemirim & 557.97 & 76.99 & 23.01 & 0.00 & 0.14 & 0.12 & 0.12 & 0.13 \\
\hline Jerônimo Monteiro & 162.31 & 35.36 & 64.64 & 0.00 & 1.36 & 1.58 & 0.65 & 1.21 \\
\hline Mimoso do Sul & 869.08 & 32.73 & 67.27 & 0.00 & 0.43 & 0.52 & 0.51 & 0.50 \\
\hline Muniz Freire & 679,78 & 16.41 & 83.59 & 0.00 & 0.03 & 0.14 & 0.18 & 0.12 \\
\hline Muqui & 327.47 & 19.18 & 80.82 & 0.00 & 0.00 & 0.32 & 0.00 & 0.11 \\
\hline Piúma & 74.08 & 84.98 & 15.02 & 0.00 & 0.24 & 0.46 & 0.27 & 0.32 \\
\hline Presidente Kenedy & 586.99 & 78.37 & 21.59 & 0.04 & 0.25 & 1.02 & 0.04 & 0.43 \\
\hline Rio Novo do Sul & 203.78 & 30.15 & 69.85 & 0.00 & 0.01 & 0.10 & 0.05 & 0.05 \\
\hline Santa Leopoldina & 272.78 & 21.93 & 78.07 & 0.00 & 0.06 & 0.08 & 0.08 & 0.07 \\
\hline São José doCalçado & 715.68 & 27.39 & 72.61 & 0.00 & 0.17 & 0.17 & 0.16 & 0.17 \\
\hline Viana & 312.19 & 41.10 & 58.90 & 0.00 & 0.01 & 0.04 & 0.01 & 0.02 \\
\hline Vila Velha & 210.71 & 95.87 & 4.13 & 0.00 & 0.00 & 0.03 & 0.00 & 0.01 \\
\hline
\end{tabular}

Data provided by a slaughterhouse in Anchieta city, in the south of the state.

spots closer to predominance limits are interpolated, thus generating an estimative of values of samples from a known number.

Martins et al. [9] described that the cities of Jerônimo Monteiro, Alegre and Cachoeiro de Itapemirim are favorable for the disease, since they are inserted into high risk areas with more than $50 \%$ of their territorial extensions suitable for $F$. hepatica development. These values of favorability are applicable to the present results, in which data provided by slaughterhouses show that percentages are higher in the southern region of the State.

In the current study, it was observed that the lowest rates of infection were found in the metropolitan areas, in Serra do Caparaó and mountainous regions with averages between 0.01 to $0.13 \%$ (Figure 4). These high altitude areas are composed of cities that have unfavorable conditions for the development of F. hepatica (Table 3).

Mas-Coma et al. [18] found the parasite F. hepatica and Lymnaea snails in the Bolivian highlands (more than $3800 \mathrm{~m}$ altitude). It is known that the transmission of the parasite is facilitated in low altitudes, because in high altitudes less oxygen is available, temperature is more extreme and solar radiation is elevated. Thus, animals raised in such places may show different morphological and physiological features from those living in low lands [28].

Mas-Coma et al. [18] observed that altitude effects are possibly softened by the solar incidence. These areas located in the tropics present absence of dense vegetation, porous soil and other factors. These variables could directly favor higher temperature and rainfall rates. Such 
factors combined with shallow water tables on the soil would consequently lead to permanent water backlog in such places.

Although Figure 3 showed that Colatina appeared among the places affected by fasciolosis, it is known that the city is located in a zone unsuitable for the parasite (Table 3). Colatina does not border areas with positive cases. It is interesting to observe that data from slaughterhouses showed that it can possibly be part of a region facing a fasciolosis outbreak (Figure 4). This case highlights that it is important to analyze data as a whole in order to a get a complete picture of the situation, which would positively influence the decision-making process regarding public healthcare policies.

\section{Conclusions}

Considering the data provided by federal and state inspection systems (SIF and SIE), a slaughterhouse in Anchieta and generated maps, it can be observed that southern Espírito Santo showed the highest prevalence for fasciolosis, which corroborates previous studies.

Although collected data suggested a prevalence pattern based on bioclimatic maps, this observation was not true for several cities, particularly those in the north of the state. This may be attributable to a few facts including that data from slaughterhouses do not reflect the real origin of animals and to trade of animals among farmers.

Control strategies including stricter surveillance of animal transport by competent organs may effectively prevent the occurrence of new cases in regions considered free of the disease. Because when the presences of the parasite and its intermediate host are already observed, the control of fasciolosis becomes expensive and less effective.

\section{Competing interests}

The authors declare that there are no competing interests.

\section{Authors' contributions}

IVFM: project coordinator. DFF: performed all the research. GMADAS, ARS and DSG: responsible for GIS and statistical analysis. All authors read and approved the final manuscript.

\footnotetext{
Author details

${ }^{1}$ Graduate Program in Veterinary Sciences, School of Veterinary Sciences, Federal University of Espírito Santo, Alegre, Espírito Santo State, Brazil. ${ }^{2}$ Graduate Program in Pharmaceutical Sciences, School of Pharmaceutical Sciences, University of Vila Velha, Vila Velha, Espírito Santo State, Brazil. ${ }^{3}$ Graduate Program in Forest Sciences, School of Forest Sciences, Federal University of Espírito Santo, Alegre, Espírito Santo State, Brazil. ${ }^{4}$ Fluminense University Center (UNIFLU), Campos dos Goytacazes, Rio de Janeiro State, Brazil. ${ }^{5}$ Centro de Ciências Agrárias, Universidade Federal do Espírito Santo, Alegre, Espírito Santo, Brasil.
}

Received: 19 December 2013 Accepted: 18 June 2014 Published: 29 July 2014

\section{References}

1. Fuentes MV: Remote sensing and climate data as a key for understanding fasciolosis transmission in the Andes: review and update of an ongoing interdisciplinary project. Geospat Health 2006, 1(1):59-70.

2. Mas-Coma S: Epidemiology of fascioliasis in human endemic areas. J Helminthol 2005, 79(3):207-216.

3. Bennema S, Ducheyne E, Vercruysse J, Claerebout E, Hendrickx G, Charlier J: Relative importance of management, meteorological and environmental factors in the spatial distribution of Fasciola hepatica in dairy cattle in a temperate climate zone. Int J Parasitol 2011, 41(2):225-233.

4. Pile E, Santos JAA, Pastorello T, Vasconcelos M: Fasciola hepatica em búfalos (Bubalus bubalis) no município de Maricá, Rio de Janeiro, Brasil. Braz J Vet Res Anim Sci 2001, 38(1):288-289.

5. Ueta MT: Alguns aspectos da biologia de Lymnaea columella Say, 1817 (Gastropoda, Pulmonata). Rev Saude Publica 1976, 10:355-366.

6. Lutz A: Sobre a ocorrência de Fasciola hepática, no Estado do Rio de Janeiro. Bol Inst Oswaldo Cruz 1921, 1(1):9-13.

7. Serra-Freire NM: Fasciolose hepática. Hora Vet 1995, 1:13-19.

8. Oliveira SM, Spósito Filha E: Divulgação técnica: Fasciolose hepática. Arq Inst Biol São Paulo 2009, 71(1):5-7

9. Martins IVF, de Avelar BR, Pereira MJ, da Fonseca AH: Application of a geographical information system approach for risk analysis of fascioliasis in southern Espírito Santo state. Brazil Geospat Health 2012, 6(3):S87-S93.

10. Martins IVF, Bernardo CC, Avelar BR, Araújo IBBA, Donatele DM, Nunes LC: Sensibilidade e reprodutibilidade da técnica de sedimentação (Foreyt, 2005) para o diagnóstico de Fasciola hepatica. Rev Bras Parasitol Vet 2008, 17(1):110-112.

11. Fuentes MV, Sainz-Elipe S, Nieto P, Malone JB, Mas-Coma S: Geographical Information Systems risk assessment models for zoonotic fascioliasis in the South American Andes region. Parassitologia 2005, 47(1):151-156.

12. Ometto JC: Bioclimatologia Vegetal. São Paulo: Agronômica Ceres; 1981.

13. Toledo JV, Martins LD, Klippel VH, Pezzopane JEM, Tomaz MA, Amaral JFT: Zoneamento agroclimático para a cultura do pinhão-manso (Jatropha curcas L.) e da mamona (Ricinus communis L.) no Estado do Espírito Santo. Agr Cient Semi-Árido 2009, 5:41-51.

14. Alves AR, Vianello RL: Meteorologia básica e aplicações. Viçosa: UFV; 2004.

15. Thornthwaite CW, Matter JR: The Water Balance. Centerton, New Jersey: Drexel Institute of Technology - Laboratory of Climatology; 1955 (Publications in Climatology, Volume 8, n.1).

16. Rapsch C, Dahinden T, Heinzmann D, Torgerson PR, Braun U, Deplazes P, Hurni L, Bar H, Knubben-Schweizer G: An interactive map to assess the potential spread of Lymnaea truncatula and the free-living stages of Fasciola hepatica in Switzerland. Vet Parasitol 2008, 154(3-4):242-249.

17. Mas-Coma S, Valero MA, Bargues MD: Climate change effects on trematodiases, with emphasis on zoonotic fascioliasis and schistosomiasis. Vet Parasitol 2009, 163(4):264-280.

18. MasComa S, Funatsu IR, Bargues MD: Fasciola hepatica and lymnaeid snails occurring at very high altitude in South America. Parasitology 2001, 123:S115-S127.

19. Landim PMB: Análise estatística de dados geológicos. $2^{\circ}$ edição. São Paulo: UNESP; 2003.

20. Tum S, Puotinen ML, Copeman DB: A geographic information systems model for mapping risk of fasciolosis in cattle and buffaloes in Cambodia. Vet Parasitol 2004, 122(2):141-149.

21. Bernardo CC, Carneiro MB, Avelar BR, Donatele DM, Martins IVF, Pereira MJS: Prevalence of liver condemnation due to bovine fasciolosis in Southern Espírito Santo: temporal distribution and economic losses. Rev Bras Parasitol Vet 2011, 20(1):49-53.

22. Alves DP, Carneiro MB, Martins IVF, Bernardo CC, Donatele DM, Pereira Júnior OS, Almeida BR, Avelar BR, Leão AGC: Distribution and factors associated with Fasciola hepatica infection in cattle in the south of Espírito Santo State, Brazil. J Venom Anim Toxins Ind Trop Dis 2011, 17(3):271-276 [http:// www.scielo.br/scielo.php?script=sci_arttext\&pid=S1678-91992011000300006]

23. Dutra LH, Molento MB, Naumann CRC, Biondo AW, Fortes FS, Savio D, Malone JB: Mapping risk of bovine fasciolosis in the south of Brazil using Geographic Information Systems. Vet Parasitol 2010, 169(1-2):76-81.

24. Faria RN, Cury MC, Lima WS: Prevalence and dynamics of natural infection with Fasciola hepatica (Linnaeus, 1758) in brazilian cattles. Rev Med Vet 2005, 156(2):85-86

25. Abunna F, Asfaw L, Megersa B, Regassa A: Bovine fasciolosis: coprological, abattoir survey and its economic impact due to liver condemnation at 
Soddo municipal abattoir. South Ethiop Trop Anim Health Prod 2010, 42(2):289-292

26. Kithuka JM, Maingi N, Njeruh FM, Ombui JN: The prevalence and economic importance of bovine fasciolosis in Kenya-an analysis of abattoir data. Onderstepoort J Vet Res 2002, 69(4):255-262.

27. Namikawa LM: A method for triangular grid surface fitting using breaklines. Int Arch Photogram Rem Sens 1994, 30(4):362-368.

28. Valero MA, Perez-Crespo I, Khoubbane M, Artigas P, Panova M, Ortiz P, Maco $V$, Espinoza JR, Mas-Coma S: Fasciola hepatica phenotypic characterization in Andean human endemic areas: valley versus altiplanic patterns analysed in liver flukes from sheep from Cajamarca and Mantaro. Peru Infect Genet Evol 2012, 12(2):403-410.

doi:10.1186/1678-9199-20-32

Cite this article as: Freitas et al:: Bioclimatic distribution and prevalence maps for Fasciola hepatica in Espírito Santo State, Brazil. Journal of Venomous Animals and Toxins including Tropical Diseases 2014 20:32.

\section{Submit your next manuscript to BioMed Central and take full advantage of:}

- Convenient online submission

- Thorough peer review

- No space constraints or color figure charges

- Immediate publication on acceptance

- Inclusion in PubMed, CAS, Scopus and Google Scholar

- Research which is freely available for redistribution 